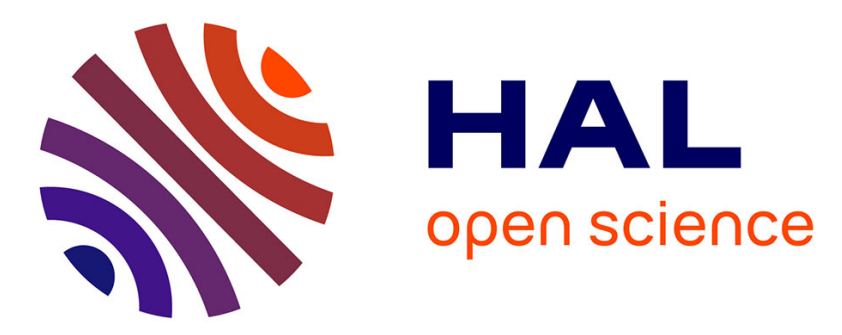

\title{
Temperature dependence of the samarium oxidation state in SmB6 and Sm1-xLaxB6
}

Jean-marie Tarascon, Y. Isikawa, Bernard Chevalier, Jean Etourneau, Paul Hagenmuller, M. Kasaya

\section{- To cite this version:}

Jean-marie Tarascon, Y. Isikawa, Bernard Chevalier, Jean Etourneau, Paul Hagenmuller, et al.. Temperature dependence of the samarium oxidation state in SmB6 and Sm1-xLaxB6. Journal de Physique, 1980, 41 (10), pp.1141-1145. 10.1051/jphys:0198000410100114100 . jpa-00208940

\section{HAL Id: jpa-00208940 https://hal.science/jpa-00208940}

Submitted on 1 Jan 1980

HAL is a multi-disciplinary open access archive for the deposit and dissemination of scientific research documents, whether they are published or not. The documents may come from teaching and research institutions in France or abroad, or from public or private research centers.
L'archive ouverte pluridisciplinaire HAL, est destinée au dépôt et à la diffusion de documents scientifiques de niveau recherche, publiés ou non, émanant des établissements d'enseignement et de recherche français ou étrangers, des laboratoires publics ou privés. 


\title{
Temperature dependence of the samarium oxidation state in $\mathrm{SmB}_{6}$ and $\mathrm{Sm}_{1-x} \mathrm{La}_{x} \mathbf{B}_{6}$
}

\author{
J. M. Tarascon, Y. Isikawa (*), B. Chevalier, J. Etourneau, P. Hagenmuller \\ Laboratoire de Chimie du Solide du C.N.R.S., Université de Bordeaux I, \\ 351, cours de la Libération, 33405 Talence, Cedex, France \\ and M. Kasaya \\ Department of Physics, Faculty of Science, Tohoku University, Sendai, Japan
}

(Reçu le 18 mars 1980, accepté le 29 mai 1980)

\begin{abstract}
Résumé. - La variation thermique du paramètre de la maille cristalline de $\mathrm{SmB}_{6}$ ainsi que des mesures d'absorption $X$ (seuil $L_{\mathrm{III}}$ du samarium) effectuées entre $4,2 \mathrm{~K}$ et $300 \mathrm{~K}$ mettent en évidence une variation du degré d'oxydation moyen du samarium qui passe de 2,60 à $300 \mathrm{~K}$ à 2,53 à 4,2 $\mathrm{K}$. Les travaux antérieurs jusqu'à présent indiquaient que le rapport $\mathrm{Sm}^{2+} / \mathrm{Sm}^{3+}$ était indépendant de la température. Un comportement analogue à celui de $\mathrm{SmB}_{6}$ a été observé pour la solution solide $\mathrm{Sm}_{0,75} \mathrm{La}_{0,25} \mathrm{~B}_{6}$.

Abstract. - The cubic lattice parameter temperature dependence of $\mathrm{SmB}_{6}$ between $300 \mathrm{~K}$ and $4.2 \mathrm{~K}$ as well as the X-ray absorption at the $\mathrm{L}_{\mathrm{III}}$ edge measured in the same temperature range, give direct evidence of the average samarium valence change which goes from 2.60 at $300 \mathrm{~K}$ to 2.53 at $4.2 \mathrm{~K}$. Previous work claimed that the $\mathrm{Sm}^{2+}: \mathrm{Sm}^{3+}$ ratio was temperature independent in $\mathrm{SmB}_{6}$. As for $\mathrm{SmB}_{6}$ a samarium valence change has been observed with decreasing temperature below $300 \mathrm{~K}$ in the $\mathrm{Sm}_{0.75} \mathrm{La}_{0.25} \mathrm{~B}_{6}$ solid solution.
\end{abstract}

Samarium hexaboride $\mathrm{SmB}_{6}$ has attracted much experimental and theoretical attention in the last few years. $\mathrm{SmB}_{6}$ is a homogeneous mixed valent compound in which the $\mathrm{Sm}^{2+}: \mathrm{Sm}^{3+}$ ratio at room temperature has been estimated to be about $4: 6$ from magnetic susceptibility, Mössbauer resonance measurements, $\mathrm{L}_{\mathrm{III}} \mathrm{X}$-ray absorption, and X-ray photoelectron spectroscopy (XPS) [1-10].

Furthermore previous Mössbauer resonance and $\mathrm{X}$-ray absorption experiments performed respectively down to $1.1 \mathrm{~K}$ and $150 \mathrm{~K}$ had not indicated significant variations of the $\mathrm{Sm}^{2+}: \mathrm{Sm}^{3+}$ ratio $[3,4,5]$. On the other hand, the lattice-parameter measurements carried out previously by us between $300 \mathrm{~K}$ and $4.2 \mathrm{~K}$ suggested a samarium valence change in $\mathrm{SmB}_{6}[5,11]$.

In the dynamic (homogeneous) mixed valence state, each rare earth ion can be viewed as fluctuating between two configurations with the $4 \mathrm{f}$ shell occupation number differing by one. The charge fluctuation time $\tau_{F}$ is such that fast measurements like X-ray absorption or XPS detect both configurations separately, while slow measurements such as Möss-

(*) Department of Physics, Tohoku University, Sendai, Japan. LE JOURNAL DE PHYSIQUE. - T. 41, No 10 , OCTOBRE 1980 bauer isomer shift detect only an average time, in the homogeneous mixed valent compounds.

In order to determine quantitatively the samarium valence change in $\mathrm{SmB}_{6}$ as a function of temperature, $\mathrm{X}$-ray absorption measurements have been carried out. The results obtained by direct observation will be compared with those deduced from lattice parameter temperature dependence.

1. Experimental. - $\mathrm{SmB}_{6}$ has been prepared according to the reaction

$$
2 \mathrm{Sm}_{2} \mathrm{O}_{3}+30 \mathrm{~B} \rightarrow 4 \mathrm{SmB}_{6}+6 \mathrm{BO} \quad[12] .
$$

Density measurements, X-ray and chemical analysis indicate an atomic ratio $\mathrm{B} / \mathrm{Sm} \simeq 6$.

The cubic lattice parameter temperature dependence of $\mathrm{SmB}_{6}$ and $\mathrm{Sm}_{0.75} \mathrm{La}_{0.25} \mathrm{~B}_{6}$ have been studied between $300 \mathrm{~K}$ and $4.2 \mathrm{~K}$ with a X-ray powder diffractometer using a monochromatic $\operatorname{CoK}_{\alpha} \mathrm{X}$-ray radiation [13].

The X-ray absorption experiments have been performed at the French synchrotron in Orsay (LURE). The X-ray beam is emitted by $1.72 \mathrm{GeV}$ electrons in the ring D.C.I. The radiation was monochromatized with the help of a (220) silicon crystal. The 
energy resolution was $2.3 \mathrm{eV}$. Intensities have been measured before and after sample through conventional ionization chambers.

2. Results and discussion. -2.1 LATTICE PARAMETER TEMPERATURE DEPENDENCE. - A change in the electronic configuration of samarium, from trivalent to divalent, with decreasing temperature has been suggested by the observation that the size of the $\mathrm{SmB}_{6}$ unit cell goes through a smooth minimum near $150 \mathrm{~K}$ (Fig. 1) [5, 11].

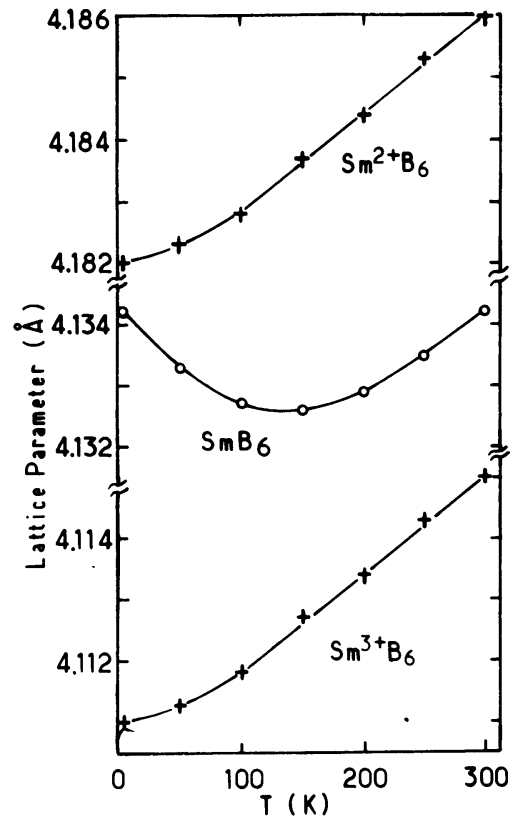

Fig. 1. - Lattice parameter temperature dependence of the cubic unit cell of $\mathrm{SmB}_{6}$ (experimental) and of the hypothetical hexaborides $\mathrm{Sm}^{2+} \mathrm{B}_{6}$ and $\mathrm{Sm}^{3+} \mathrm{B}_{6}$ (calculated).

An estimate of the average samarium valence in $\mathrm{SmB}_{6}$ may be deduced at any temperature from the cubic lattice parameter temperature dependence. $\mathrm{SmB}_{6}$ can be considered as a solid solution between the hypothetical hexaborides $\mathrm{Sm}^{2+} \mathrm{B}_{6}$ and $\mathrm{Sm}^{3+} \mathrm{B}_{6}$ for which the lattice parameters have been interpolated from those of neighbouring divalent and trivalent rare earth hexaborides. We can deduce the thermal expansion of the unit cell of $" \mathrm{Sm}^{2+} \mathrm{B}_{6}$ " and " $\mathrm{Sm}^{3+} \mathrm{B}_{6}$ " below $300 \mathrm{~K}$ from those of the other hexaborides $\left(\mathrm{YbB}_{6}, \mathrm{SrB}_{6}, \mathrm{LaB}_{6}\right)$ for which the thermal variation of the lattice parameter is approximately the same.

It is worthwhile to note that in the systems $\mathbf{M}_{1-x}^{2+} \mathbf{M}_{x}^{3+} \mathbf{B}_{6}$ the variation of the cubic lattice parameter does not follow a Vegard rule. For instance, the variation of the lattice parameter in the $\mathrm{Eu}_{1-x}^{2+} \mathrm{La}_{x}^{3+} \mathrm{B}_{6}, \quad \mathrm{Eu}_{1-x}^{2+} \mathrm{Gd}_{x}^{3+} \mathrm{B}_{6}$ and $\mathrm{Yb}_{1-x}^{2+} \mathrm{Gd}_{x}^{3+} \mathrm{B}_{6}$ system shows a concave curve. This deviation from a Vegard rule is due to the presence of electrons in the $5 \mathrm{de}_{\mathrm{g}}$ conduction band $[14,15]$. These results have been used to estimate the deviation in a theoretical
$\mathrm{Sm}_{1-x}^{2+} \mathrm{Sm}_{x}^{3+} \mathrm{B}_{6}$ solid solution. The variation of the lattice parameter of $\mathrm{Sm}_{1-x}^{2+} \mathrm{Sm}_{x}^{3+} \mathrm{B}_{6}$ as a function of $x$ is given in figure 2 at $300 \mathrm{~K}$.

With such an approach, the experimental value of the $\mathrm{SmB}_{6}$ lattice parameter at $300 \mathrm{~K}$

$$
\left(a=4.1342 \pm 5 \times 10^{-4} \AA\right)
$$

corresponds to $x \simeq 0.6$, that is, 2.60 for the average samarium valence in $\mathrm{SmB}_{6}$. This result agrees well with those obtained by magnetic measurements and XPS studies [7, 8].

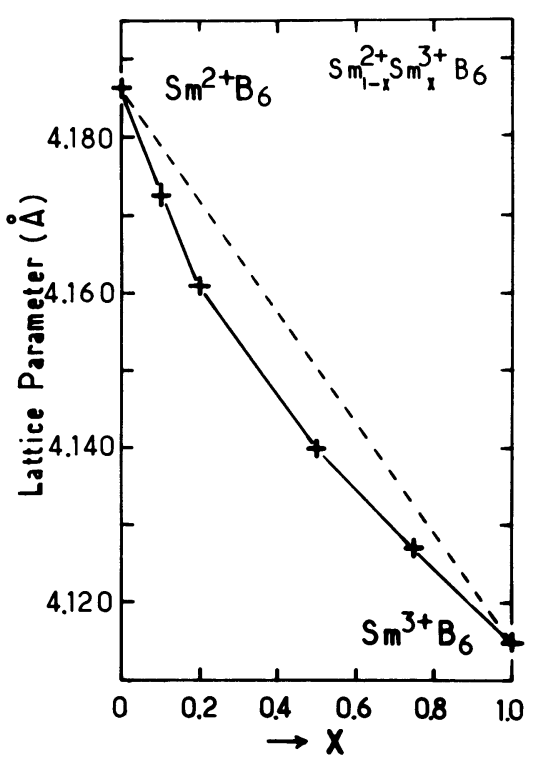

Fig. 2. - Calculated variation of the cubic lattice parameter as a function of $x$ at $300 \mathrm{~K}$ for the $\mathrm{Sm}_{1-x}^{2+} \mathrm{Sm}_{x}^{3+} \mathrm{B}_{6}$ system.

The variation of the lattice parameter of $\mathrm{Sm}_{1-x}^{2+} \mathrm{Sm}_{x}^{3+} \mathrm{B}_{6}$ as a function of $x$, calculated at any temperature between $300 \mathrm{~K}$ and $4.2 \mathrm{~K}$, and the temperature dependence of the lattice parameter of $\mathrm{SmB}_{6}$, allowed us to propose the variation of the average samarium valence as a function of temperature (Fig. 3).

As the temperature decreases from $300 \mathrm{~K}$ down to $4.2 \mathrm{~K}$ the average samarium valence change in $\mathrm{SmB}_{6}$ goes from 2.60 to 2.53 , corresponding to an increase of $17.5 \%$ of $\mathrm{Sm}^{2+}$ ions.

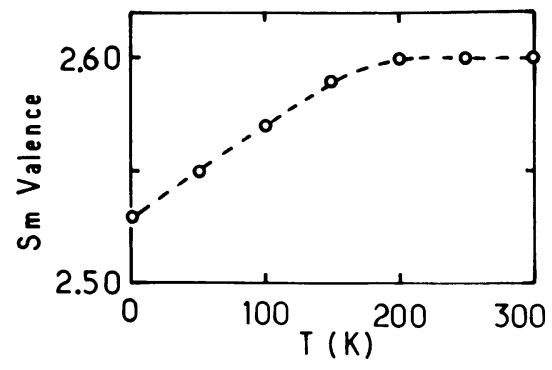

Fig. 3. - Average samarium valence temperature dependence in $\mathrm{SmB}_{6}$ between $300 \mathrm{~K}$ and $4.2 \mathrm{~K}$. 
2.2 X-RAY ABSORPTION. - X-ray absorption at the $\mathrm{L}_{\text {III }}$ edge has been measured from $300 \mathrm{~K}$ to $4.2 \mathrm{~K}$ in $\mathrm{SmB}_{6}$. The structure of the absorption spectrum within a few eV of an edge allows to extract the fractional valence of the bulk to within a few \% [3].

The $\mathrm{L}_{\mathrm{III}}$ absorption spectra obtained consist of two peaks corresponding to the spectral components of $\mathrm{Sm}^{2+}$ and $\mathrm{Sm}^{3+}$ valence states separated by $7 \mathrm{eV}$ (Figs. 4 and 5).

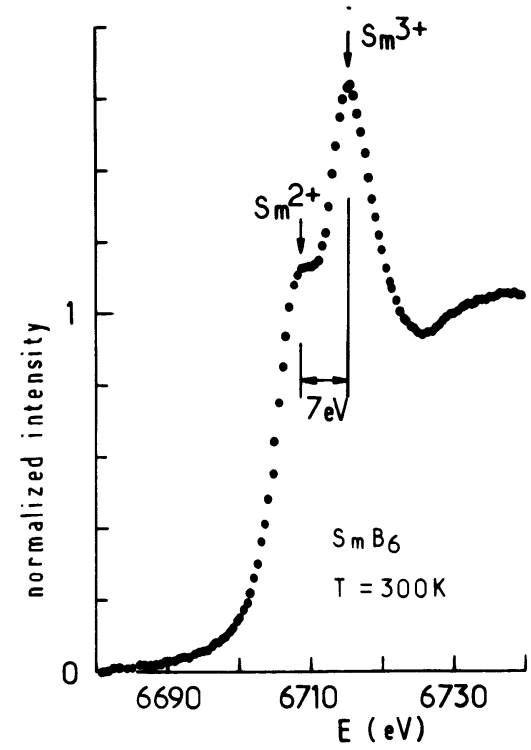

Fig. 4. - Structure of the $\mathrm{SmL}_{\text {III }}$ absorption edge in $\mathrm{SmB}_{6}$ at $300 \mathrm{~K}$ (sample outside the cryostat).
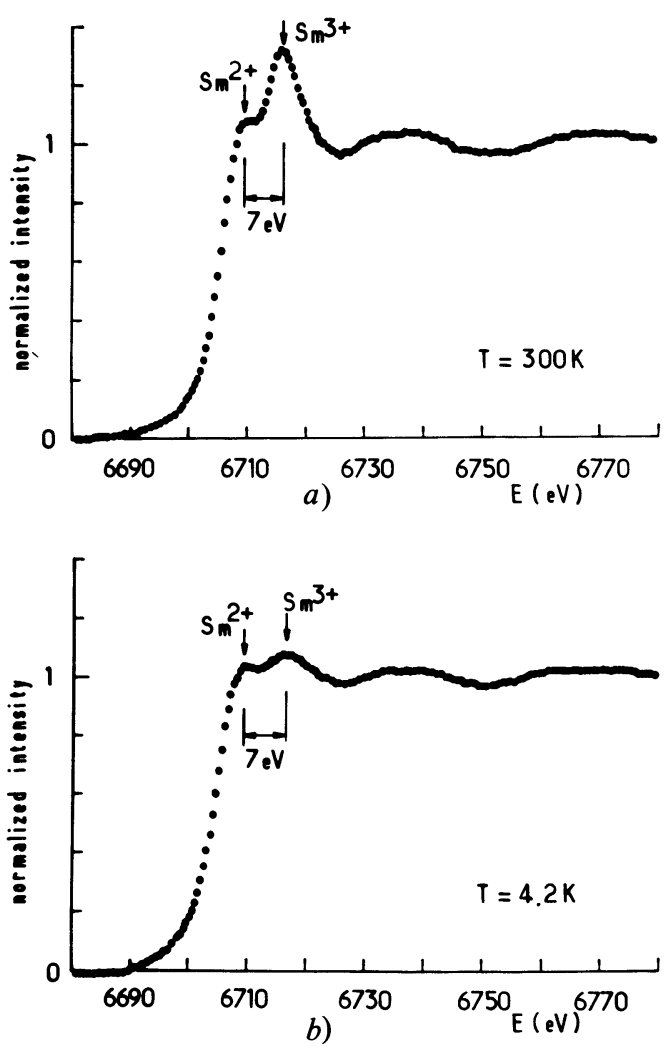

Fig. 5. - Structure of the $\mathrm{SmL}_{\mathrm{III}}$ absorption edge in $\mathrm{SmB}_{6}$ (sample inside the cryostat). a) at $300 \mathrm{~K} ; b)$ at $4.2 \mathrm{~K}$.
The difference in intensities of the $\mathrm{Sm}^{2+}$ and $\mathrm{Sm}^{3+}$ lines between the spectra given in figures 4 and $5 a$ comes from changes in sample thickness and homogeneity. The intensity of the $\mathrm{Sm}^{3+}$ peak, with respect to that of $\mathrm{Sm}^{2+}$ peak, decreases as the temperature decreases. The difference between the absorption curve before the edge and the mean absorption averaged over the EXAFS oscillations after the edge is normalized to one.

The absorption curves have been plotted considering the fact that the shape of the $\mathrm{L}_{\text {III }}$ absorption edge remains unchanged whatever the oxidation state (+ II or + III) of a given rare earth cation in the hexaborides [3]. Then, the $\mathrm{L}_{\text {III }}$ absorption spectrum of $\mathrm{Eu}^{2+}$ in $\mathrm{EuB}_{6}$ has been chosen as reference and the analysis of the experimental absorption curves has been made by fractional superposition of two EuB $_{6} \mathrm{~L}_{\text {III }}$ absorption spectra shifted with respect to each other by $7 \mathrm{eV}$ (Fig. 6).

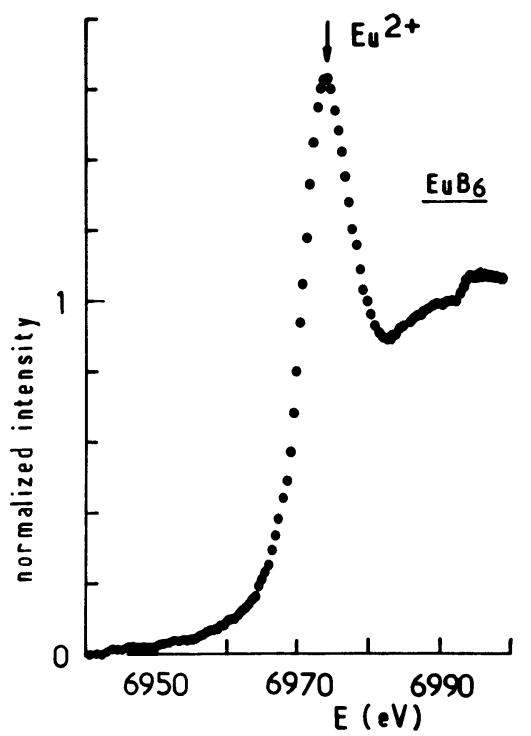

Fig. 6. - Structure of the $\mathrm{Eu}^{2+} \mathrm{L}_{\mathrm{III}}$ absorption edge in $\mathrm{EuB}_{6}$ at $300 \mathrm{~K}$.

The plotting of the experimental $\mathrm{L}_{\mathrm{III}}$ absorption curves of $\mathrm{SmB}_{6}$ indicates a temperature dependence of the average samarium valence in good agreement with the results deduced from the lattice parameter temperature dependence. At room temperature, the average samarium valence is found to be $2.58 \pm 0.02$ and decreases about $3 \%$ as the temperature reaches $4.2 \mathrm{~K}$.

As for $\mathrm{SmB}_{6}$ itself, the average samarium valence is temperature dependent in the $\mathrm{Sm}_{1-x} \mathrm{La}_{x} \mathrm{~B}_{6}$ system. The X-ray absorption measurements at the $\mathrm{L}_{\text {III }}$ edge carried out at $300 \mathrm{~K}$ and at $4.2 \mathrm{~K}$ for $x=0.25$ indicate an increase of the $\mathrm{Sm}^{2+}: \mathrm{Sm}^{3+}$ ratio with decreasing temperature (Fig. 7). This observation is confirmed by the variation of the lattice parameter as a function of temperature, which goes through a minimum at about $200 \mathrm{~K}$ (Fig. 8). The average samarium valence deduced from the plotting of the 


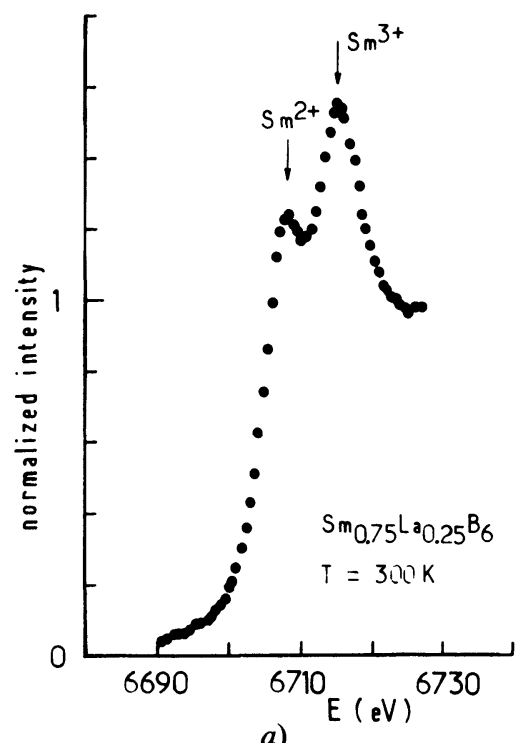

a)

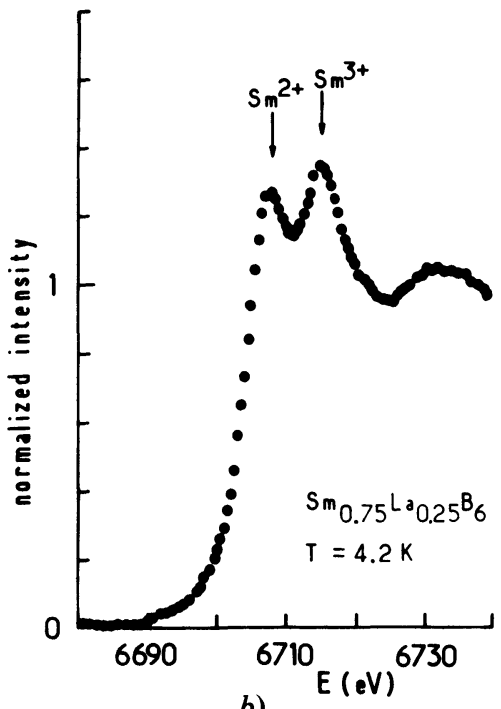

b)

Fig. 7. - Structure of the $\mathrm{SmL}_{\mathrm{III}}$ absorption edge in the $\mathrm{Sm}_{0.75} \mathrm{La}_{0.25} \mathrm{~B}_{6}$ solid solution. $a$ ) at $300 \mathrm{~K} ; b$ ) at $4.2 \mathrm{~K}$ (sample inside the cryostat).

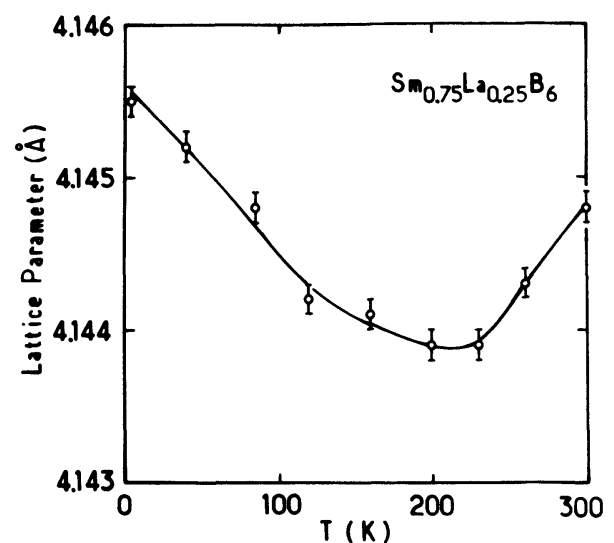

Fig. 8. - Lattice temperature dependence of the $\mathrm{Sm}_{0.75} \mathrm{La}_{0.25} \mathrm{~B}_{6}$ solid solution between $300 \mathrm{~K}$ and $4.2 \mathrm{~K}$.

$\mathrm{X}$-ray absorption spectra is in good agreement with those deduced from the lattice parameter temperature dependence : 2.44 at $300 \mathrm{~K}$ and 2.35 at $4.2 \mathrm{~K}$.

For the first time, direct evidence for a change of the electronic configuration of samarium from trivalent to divalent with decreasing temperature has been found in $\mathrm{SmB}_{6}$ and $\mathrm{Sm}_{0.75} \mathrm{La}_{0.25} \mathrm{~B}_{6}$. These compounds are considered as homogeneous mixed valent compounds : in other words, with $4 \mathrm{f}$ and $5 \mathrm{de}_{\mathrm{g}}$ conduction band states present at the Fermi level [16].

In the case of $\mathrm{SmB}_{6}$, the $5 \mathrm{de}_{\mathrm{g}}$ conduction band is occupied by about 0.6 conduction electron per $\mathrm{Sm}$ atom at $300 \mathrm{~K}$. Due to the higher electronic localization of the $4 \mathrm{f}^{6}$ level $\left(\mathrm{Sm}^{3+}+\mathrm{e}^{-} \rightarrow \mathrm{Sm}^{2+}\right)$ the number of free carriers decreases, involving an increase of the resistivity at low temperature. However, this effect is too small to explain the strong increase of the resistivity observed below $100 \mathrm{~K}$. So far, the resistivity temperature dependence below $100 \mathrm{~K}$ is explained by the presence of an energy gap near the Fermi level due to either $\mathrm{f}-\mathrm{d}$ hybridization or the formation of a Wigner lattice $[17,18]$.

Acknowledgments. - The authors thank P. Lagarde and coworkers at the Laboratoire de l'Accélérateur Linéaire (LURE) Orsay, France for their technical assistance in the X-ray absorption measurements.

\section{References}

[1] Kasuya, T., Kojima, K., Kasaya, M., Valence instabilities and Related Narrow Band Phenomena, ed. R. D. Parks (Plenum Press) 1977, p. 137

[2] Falicov, L. M. and Kimball, J. C., Phys. Rev. Lett. 22 (1969) 997.

[3] Vainshtein, E. E., Blokhin, S. M. and Paderno, Yu. B., Sov. Phys. Solid State 6 (1965) 2318.

[4] Menth, A., Buelher, E., Levinstein, H. J. and Geballe, T. H., J. Appl. Phys. 40 (1969) 1006.

[5] Menth, A., Buehler, E. and Geballe, T. H., Phys. Rev. Lett. 22 (1969) 295.

[6] Cohen, R. L., Eibschütz, M., West, K. W. and Buehler, E., J. Appl. Phys. 41 (1970) 898.
[7] Cohen, R. L., Eibschütz, M. and West, K. W., Phys. Rev. Lett. 24 (1970) 383.

[8] Chazalviel, J. N., Campagna, M., Wertheim, G. K. and SCHMid,, P. H., Phys. Rev. B 14 (1976) 4586.

[9] Aono, M., Kawai, S., Kono, S., Okusawa, M., Sagawa, T. and Takehana, Y., Solid State Commun. 16 (1974) 13.

[10] Okusawa, M., Iwasaki, Y., Tsutsumi, K., Aono, M. and KawaI, S., Japan J. Appl. Phys. 17 (1978) 161.

[11] Mercurio, J. P., Etourneau, J., Naslain, R. et HagenMUller, P., J. Less Common Metals 47 (1976) 175.

[12] Etourneau, J., Mercurio, J. P., Naslain, R. et HagenMULLER, P., Coll. Intern. du CNRS no 205 Odeillo, France, sept. 1971. 
[13] Etourneau, J., Chevalier, B. et Rabarill, L., J. Phys. E : Scientific Instruments 8 (1975) 930.

[14] Mercurio, J. P., Etourneau, J., Naslain, R., HagenMUller, P. and Goodenough, J. B., J. Solid State Chem. 9 (1974) 37.

[15] Ishit, M., Aono, M., Muranaka, S. and Kawai, S., Solid State Commun. 20 (1976) 437.
[16] Kasaya, M., Tarascon, J. M. and Etourneau, J., Solid State Commun. 33 (1980) 1005.

[17] Mott, N. F., Philos. Mag. 30 (1973) 403.

[18] Kasuya, T., Takegahara, K., Fujita, T., Tanaka, T. and BannaI, E., J. Physique Colloq. 40 (1979) C5-308. 